\title{
The role of intellectual property rights and package safety features in the prevention of counterfeit medicines
}

\author{
Katerina Ancevska-Netkovska ${ }^{1 *}$, Katerina Brezovska ${ }^{2}$, \\ Nikola Geskovski ${ }^{3}$, Jasmina Tonik-Ribarska ${ }^{2}$, \\ Biljana Petrovska-Jakimovska ${ }^{3,4}$, Blagoj Achevski ${ }^{2}$, \\ Katerina Goracinova ${ }^{3 *}$
}

\author{
${ }^{1}$ Institute of Pharmaceutical Chemistry, Faculty of Pharmacy, University "Ss. Cyril and \\ Methodius" Mother Teresa 17, 1000 Skopje, Republic of North Macedonia \\ ${ }^{2}$ Institute of Applied Chemistry and Pharmaceutical Analysis, Faculty of Pharmacy, \\ University "Ss. Cyril and Methodius" Mother Teresa 17, 1000 Skopje, Republic of \\ North Macedonia \\ ${ }^{3}$ Institute of Pharmaceutical Technology, Faculty of Pharmacy, University "Ss. Cyril \\ and Methodius" Mother Teresa 17, 1000 Skopje, Republic of North Macedonia \\ ${ }^{4}$ Alkaloid AD, Blvd. A. Makedonski 12, 1000 Skopje, Republic of North Macedonia \\ *Corresponding authors: Katerina Ancevska Netkovska, e-mail: kaan@ff.ukim.edu.mk \\ Katerina Goracinova, e-mail: kago@ff.ukim.edu.mk
}

\begin{abstract}
The fast growth of counterfeiting medicines in the last two decades has created one of the biggest problems facing the pharmaceutical industry on the global level, resulting in loss of income, product withdrawal, loss of brand value, etc. But this is not only the problem of the intellectual property rights of the pharmaceutical industry, it is also the problem of the healthcare regulatory authorities, whose most significant concern is the risk to the public health. Pharmaceutical manufacturers, together with the wholesalers and retailers, have an essential role in the fight against counterfeit medicines by the implementation of different anti-counterfeit technologies for securing the supply-chain of medicines. The protection of drug packaging has a specific role in the drug development process, as well as in the fight against counterfeit medicine. The authenticity of the medicine and the forensic elements for protection on the packaging may be confirmed using different technologies. Tracking and tracing of pharmaceutical products in the supply chain, keeping electronic records for all stages of the distribution, and verification of the authenticity of a medicinal product is a key element and an effective solution for timely detection of counterfeit medicines and protection of intellectual property rights.
\end{abstract}

Keywords: intellectual property rights, counterfeiting, medicines, drug packaging DOI: https://doi.org/10.5937/arhfarm70-28974 


\section{Introduction}

The fast growth of counterfeiting medicines in the last two decades has created one of the biggest problems facing the pharmaceutical industry on the global level. This problem addressed from the pharmaceutical industry aspect is mainly seen as a problem of a trade competition by unauthorized use of the intellectual property of the pharmaceutical industry, resulting in loss of income, product withdrawal, loss of brand value, etc. (1). Also, the global rise in online pharmacies, have widened the market for falsified drugs, which is a serious threat to public health and safety as falsified medicinal products bypass the common distribution routes and easily reach the public (2). Therefore, this problem is much more significant if being addressed as a public health risk, because of the severe consequences that may cause to the patient's health starting from lower therapeutic potential to serious side effects that can result in death.

Hence, this problem should be considered primarily from a public health perspective, but also as an intellectual property concern. Taking into account that counterfeiting of medicines is an organized crime, violating both the laws for the medicines and medical devices and regulations for the protection of the intellectual property rights of the pharmaceutical industry, the approaches for solving this issue should be based on an integrated and multilateral methodology. They should be supported by cooperation between the authorities involved, such as public health authorities and medicines agencies, as well as customs and police authorities at a national, regional, and international level, assisted by the pharmaceutical industry (3-7).

The first step that must be taken for the prevention of counterfeit medicines is the establishment, implementation, and enforcement of legislation and regulatory infrastructure concerning:

- Legislation in the field of healthcare and pharmacy

- Legislation in the field of protection of intellectual property rights;

- Legislation in the field of trading - customs legislation, the legislation of transportation and storage;

- Legislation in the field of fight against organized crime - discovery and sanction of the falsified medicines;

In July 2011, the European Union (EU) strengthened patient and consumer protection by the introduction of new directive 2011/62/EU also known as EU Falsified Medicines Directive (EU FMD) (8) aimed to prevent counterfeit medicines from entering the supply chain and reaching the patient. The directive introduced harmonized safety and strengthened control measures throughout the whole of Europe by applying standards which include the introduction of safety features of the packaging of medicines, strengthened requirements for active substances and medicine distribution as well as regulation of internet sale of drugs (9). The Commission Delegated Regulation 2016/161 defines the requirements for the identification and confirmation system of the authenticity 
of the medicines in the distribution chain using package safety features (Unique Identifier and Anti tampering device). According to this Regulation, the identity and authenticity of medicinal products are guaranteed by an end-to-end verification of all medicinal products bearing the safety features (10). To minimize the online-based falsified medicine frauds, the abovementioned Regulation and Directive also introduced a common logo for the websites of legal online pharmacies and approved merchants allowing the patients and consumers to easily identify authorized online pharmacies with approved and authenticated medicines.

The national laws regulate the protection of intellectual property rights, and additionally, the Trade-related Aspects of Intellectual property rights (TRIPS) Agreement is applicable on an international level.

Pharmaceutical manufacturers have a crucial role in the prevention and early detection of counterfeited medicines, by the establishment of a strategy for the protection of their intellectual property rights and by providing transparency and traceability with an application of new technologies for identification and confirmation of the authenticity of the products in all stages of the distribution chain.

\section{Intellectual property rights in the prevention of counterfeit medicines}

Intellectual property rights (IPRs) play a vital role in the modern economy, being a robust tool, for the protection of the investments, time, money, and effort of the intellectual property inventor, granting him an exclusive right for using his invention for a specific period.

IPRs are defined as mechanisms for the protection of ideas, patents, and innovations, taking into consideration the protection of trademarks, industrial design, or copyrights in every link of the supply chain, and are an essential tool in the fight against counterfeit medicines (11).

But, in consideration of the role of the intellectual property rights in the prevention of counterfeit medicines, the restricted period of validity of IPRs, and the exclusivity of the innovator's idea, the patent or the innovation must be taken into account. Additionally, the patent provides exclusive rights with a chance for industrial applicability of the innovation or achieving society value (12). The main issue of patent protection is the obligatory publication of technical information that can be useful for counterfeiters.

The patent rights have invaluable importance, for the brand protection of pharmaceutical products as well as the protection of their trademarks. Pharmaceutical product brands are designed for the promotion and recognition of pharmaceutical companies, and also for gaining loyalty and trust by the customers.

Branded products also dictate the market price when compared to non-protected, non-branded, and generic medicines, giving the benefit to the pharmaceutical industry from the investment in protection and conduction of suitable strategy for protection of 
intellectual property. Patients are aware of paying a higher price for branded medicine, with gained trust in comparison to a medicine that has not been recognized as a brand (13). Building up a brand involves time and investment for every manufacturer, which in combination with a good marketing campaign, results in a dominant role in the market and enormous profit. Consumer opinion for the brand can change through time, in a positive or negative connotation. Unwanted events can cause damage to the image, and the value of the brand, so-called "brand erosion". Brand erosion phenomenon can be subtle and gradual or catastrophic and unexpected. Information about the counterfeited product, mentioning the name of the original brand and holder of corporate rights, may gradually project a negative image in the customer perspective, causing damage in the future marketing of the branded product. In these cases, the patients may search for alternative medicine from another manufacturer. Recovery of the market share loss and renewal of the image of the brand, requires additional marketing costs, causing profit loss. Furthermore, the downfall of the brand can reduce the confidence of the public in the pharmaceutical company, affecting the marketing of other products of the manufacturer.

The price that pharmaceutical companies pay, as a result of the counterfeit medicines, is high. The effects of this phenomenon on the pharmaceutical industry include reduction of employment, reduction in the investments in research and development, and at the same time investment of a lot of money in marketing to rebuild the clients' trust.

Before being released for use and market, branded medicines manufactured by the pharmaceutical companies go through many regulatory filters to ensure that the products are safe, efficient, and of suitable quality. Additionally, the pharmaceutical industry has to invest in building the trust of doctors, pharmacists, and the public and convince them that they are prescribing the best medicine for a patient's needs. By using the Internet, patients have easier access to information about the medicines and an option to participate in the selection of suitable medication for their needs. But the available information usually does not include the authenticity check of the medicine (14).

If the quality and safety of medicines are questionable for the public then the trust in the whole medical system will be lost, harming the pharmaceutical industry as well, as financial loss.

\section{Packaging safety features as protection from counterfeiting}

The main function of the packaging (primary, secondary and tertiary) is to protect the medicine, to assure the safe and correct use of the medicine, and to provide information about the identity, instruction of how to use, and store the medicine $(15,16)$. Primary packaging is in direct contact with the product, providing protection of the finished product from environmental conditions and influences during transport and storage, enabling identification of the product, and for some medicines providing childproof protection. Secondary packaging is not in direct contact with the finished product 
and may contain a certain number of primary packages for additional mechanical or protection against environmental conditions such as light, temperature, moisture, or further information about the product. Tertiary packaging contains a certain number of secondary packages, and its role is to provide easy and safe transport, distribution, and storage of the product.

The authenticity of the medicine may be confirmed using different technologies for visible or invisible features and forensic protection on the packaging (17). Visible features or visible protection can be easily seen with the naked eye and may include security labels, holograms, special ink, microstructural markers, and anti-tampering devices (18).

\section{Security labels}

One of the advantages of using security labels is their small dimensions, the possibility of easy modification or manipulation, and low cost (19). A security label can be manufactured from different materials, for example, polymers, paper, or metal, which may be additionally processed to reflect visual effects and can perform a double function, by providing information about the product and as an anti-tampering device. The material should be temperature and moisture stable. The pharmaceutical industry uses four types of labels: simple self-adhesive labels, rubberized labels, thermosensitive labels, and most commonly used pressure-sensitive labels. Security labels are applied with compression on an automated labeling machine, during the final packaging process. Usually, the label contains an adhesive layer on one side, enabling tamper-proof when removed from the packaging (damage of the label itself or the surface under the label). Another approach is the application of labels with high friability, designed in a way that the label will tear into small fragments when trying to remove from the package where it is applied. Usually, the labels are printed with additional visible or invisible features. The use of labels is strictly regulated and following the good manufacturing practice (GMP) standards. Labels are stored in strictly controlled conditions at an optimal temperature, moisture, and pressure.

\section{Holograms}

Holograms are part of a larger group of technologies and devices called Diffractive optically variable image devices (DOVIDs) and represent labels that use diffraction of light to reproduce a sophisticated visual effect (20). There are multiple hologram types, depending on the type effect they reproduce:

- two-dimensional - producing a two-dimensional image;

- two-dimensional/three-dimensional - have layers that create a two-dimensional and two-dimensional image;

- three-dimensional - creates a fully three-dimensional image;

- Stereogram - creates animation effect produced by sequences or film images, video or computer graphics; 
Holograms are used as visible features, enabling the pharmacists and patients to recognize and verify the authenticity of the product and to distinguish the genuine from counterfeit medicine. Holograms may also include a visible or invisible unique serial number, providing authenticity and traceability of the product, as well as additional hidden elements detectable only with laser scanners or decoders.

\section{Special inks}

Special inks that can change their color when changing the viewing angle are often used by the pharmaceutical industry (19), including:

- Iridescent inks, providing a "rainbow" effect with multiple visible colors when changing the angle of view of the surface. The difference between iridescent inks and other inks is that iridescent one have a gradual transition of multiple colors at the same time with the so-called "soap bubble" effect, whilst the other inks have a color transition with the so-called "flip-flop" effect;

- Inks with metallic colors that give golden, silver, cupric effect are often combined with iridescent inks for better effect. The disadvantage of these inks is that they are cheap and easily accessible for counterfeiters;

- Fluorescent inks, providing the emission of light (one or two colors) following absorption of light with different wavelengths in the UV spectrum (fluorescence).

- Thermochromic inks, providing a color change, as a result of a reversible reaction caused by a change of temperature (21). The initial color appears after a couple of seconds when the temperature decreases below the critical point. The inks that change their color at body temperature $\left(36^{\circ} \mathrm{C}-37^{\circ} \mathrm{C}\right)$ when touched with a finger are most widely used. There are also irreversible thermochromic inks which are mostly used for vaccines and blood products because the stability of these products depends on the stability of temperature in manufacturing, transportation and storage. Change of the packaging color will be the main indicator for an inefficient and toxic product;

- Photochromic inks, providing color change after being exposed to UV light and return to the initial color in several seconds after removing the UV light source;

- Inks that react when they are in contact with metal, and they usually combine with other types of inks;

\section{Microstructural markers}

Particles containing information (codes, words. or logo), with a micrometric dimensions, which can be identified under a microscope, are also used (19). These particles are added to the special inks, lacquers or incorporated in the primary packaging, glass containers, blisters, etc. 


\section{Infrared absorbing inks}

Infrared absorbing inks or up-converters are powerful security tools against counterfeiting, based on radiation of light visible to the naked eye, following absorption of infrared light (based on the conversion of infrared light with lower energy and higher wavelength to visible light with higher energy and lower wavelength) (22). Visualization of these inks requires sophisticated electronic detectors and powerful energy sources. These detectors are calibrated to recognize specific ink, and a positive signal is obtained only if the ink is present in the required amount.

\section{Anti-tampering devices}

An anti-tampering device is a safety feature, allowing the verification of whether the packaging of a medicinal product has been tampered with. Safety features consisting of a unique identifier and an anti-tampering device on the packaging of certain medicinal products for human use are part of the measures for prevention of the entry into the legal supply chain of falsified medicinal products in the EU and are mandatory in EU member states since $9^{\text {th }}$ of February 2019 (10). Verification of the integrity of the packaging is performed using a visual or audio indicator or seal for opening the packaging as protection, indicating whether the packaging was opened before the first use (23). In 1983, the FDA introduced the concept of Tamper-resistant packaging used for over-thecounter (OTC) products marketed in the USA. However this term wasn't widely accepted by the manufacturers, and therefore FDA recently renamed it to tamper-evidence, based on its property to indicate the opening of the product before its first use. It is essential to know whether the packaging of the medicine was opened before and if someone tampered with its content, removed, diluted, changed, or exposed it to pollution. The anti-tampering system is used to ensure that the product is packed in its original packaging and has not been altered and additionally to protect the product from moisture, bacteria, and other external conditions.

Visible safety characteristics are important and useful for patients. But for better protection of their products, pharmaceutical companies also apply invisible or hidden elements. There are multiple technologies for invisible characteristics that can be detected with unique technology.

\section{Forensic markers}

The use of forensic inks is one of the most sophisticated ways to protect pharmaceutical products (17). Materials used as markers are always treated as strictly confidential and are available only to a limited number of employees in the pharmaceutical company because this type of protection is the last line of the chain in the fight against counterfeit medicines. There are multiple types and technologies for forensic markers: 
- Isotope markers - isotope substitution of an existing molecule. This isotope changes the mass of the molecule, but it doesn't change its chemical structure. Because the isotopes are found in low concentration it is challenging to detect them without sophisticated equipment;

- DNA markers - short synthetic DNA fragments with specific nucleotide sequence which are added to the matrix of the labels or special inks. DNA signal is detected with the technique of opposite complementary segment of DNA carrying a fluorescent marker which is activated when it binds with the DNA fragment. Binding and interaction of the two DNA strands gives the fluorescent signal;

- Antibodies system - similar to the DNA marking this system involves the incorporation of antibodies and identifying them through protein binding analysis. The main disadvantage of this system is the high price and the special conditions which are required by the antibodies;

- Specific markers which can be detected with X rays - this technique does not need expensive equipment and technology, but the instruments are robust and require a lot of space;

\section{Track and trace systems}

Track and trace systems allow product locating throughout the supply chain and finding information about the product such as historical locations, time spent at each location, record of ownership, transaction history, packaging configurations, storage conditions, etc. Enhanced verification and tracing in the supply chain facilitates the detection of counterfeit medicines and allows more rapid response by industry and the competent authorities for investigation of packagings with illicit content and illegitimate medicines (24). Recently, different technologies have been developed and adopted for the identification and tracking of medicinal products through the supply chain and verification of each product down to the packaging level:

- Universal Product Code (UPC) containing 12 numbers with a sequence that is uniquely assigned to each pharmaceutical product. Together with the EAN barcode, the UPC barcode is mainly used for scanning the medicines at the counter, according to the GS1 specifications;

- Human Readable Codes - based on the ISBN which is a combination of numbers and letters combined in a unique way which gives uniqueness to every individual package;

- 2D Matrix Codes - two-dimensional barcode printed in a square or rectangular format, which is a combination of black and white individual dots and squares spread within a network of white and black surfaces. The data within the DataMatrix are coded with symbols and contain information about the product (date of manufacturing, shelf life, serial number, dimensions, etc.). 2D matrix codes are printed on a white background with visible or invisible, hidden ink. 
Hidden codes are printed with special secure inks on a colored background or graphic elements. Printing of the 2D matrix codes is performed throughout the process of secondary packaging, and at the same time, the data for each package are entered into the database. The database is amended with information regarding storage and transportation until the final dispensing of the medicine to the patient. 2D matrix codes are an important tool for increasing the safety of the medicines by increasing the tracking in the supply chain. The main disadvantage of these codes is that the coda has to be adjacent to the scanner, which may cause problems for the distributors that manipulate with tertiary packaging;

- 3D Matrix Codes - specific three-dimensional combination of codes, representing the serial number of the medicine;

- Property Codes - unique graphic illustration depicting the serial number of the medicine;

- Radio Frequency Identification (RFID) - is a technology that uses radio waves to automatically track medicines and associate programmed information providing authentication of the individual package. This system is composed of a tag, a reader, an antenna, and software. There is no need for unique signs on the packaging; radio waves can penetrate even through non-transparent materials. Multiple packages packed in a tertiary package can be individually detected without the need to unpack and repack the tertiary packaging. This is an important advantage, especially for the big distribution centers. Another advantage of this method is that the maximal distance between the RFID marker and reader can be significantly longer. RFID chips that are used are small enough to be incorporated in every label on individual packaging. These chips can be active or passive. The active ones have their source of energy (battery) and usually are bigger and more expensive than the passive ones. They also have read-write technology which means that the information on the chip can be upgraded. This chip contains every piece of information about the product. Although there are a lot of advantages, this technology also has some disadvantages that limit its use in the pharmaceutical industry, including the high price of the equipment used and the chips needed to be installed in each package.

\section{Conclusion}

Counterfeiting of medicines is one of the most significant issues affecting the pharmaceutical industry in the last several years. But this is not only the problem of the intellectual property rights of the pharmaceutical industry; it is also the problem of the healthcare regulatory authorities, whose greatest concern is the risk to the public health. The fight against counterfeit medicines includes a multilateral approach based on the establishment and implementation of legislation and the development of a strategy for cooperation between competent authorities on a national and a global level. 
Pharmaceutical manufacturers, together with the wholesalers and retailers, have an essential role in the fight against counterfeit medicines by the implementation of different anti-counterfeit technologies for securing the supply chain of medicines. Tracking and tracing of pharmaceutical products, keeping electronic records for all stages of the distribution, and verification of the authenticity of a medicinal product is a key element and an effective solution for timely detection of counterfeit medicines and protection of intellectual property rights.

Most of the countries have already established a legal basis that supports the fight against falsified medicines, and the regulatory authorities for medicines, together with the pharmaceutical industry are already taking actions to build an effective track and trace system for securing the supply chain. Additional measures are taken from competent authorities for increased criminal enforcement and penalties for counterfeiters. But, in some countries, there is a lack of established measures implementation, and the counterfeiters use the existing regulatory gaps of the criminal law and the law for intellectual property rights.

Regulatory compliance for serialization is increasingly becoming an area of focus for pharmaceutical manufacturers as well as supply chain partners. The regulatory pressure to secure the drug supply chain is a result of increased criminal activities related to medicines and inefficiency, and weaknesses in the supply chain. Efforts are being made to prevent counterfeit medicines and unauthorized parallel supply chains, as well as to improve the supply chain transparency and difficulties in tracking and tracing of medicines.

\section{References}

1. OECD. Trade in Counterfeit Pharmaceutical Products. Paris: OECD Publishing; 2020. (Illicit Trade).

2. Clark F. Rise in online pharmacies sees counterfeit drugs go global. Vol. 386, The Lancet. Lancet Publishing Group; 2015. p. 1327-8.

3. Council of Europe. Ad hoc group on counterfeit medicines (P-SP-PH/CMED) national and international co-operation to combat counterfeiting of medicines and pharmaceutical crimes: a model for a network and single points of contact (spocs). Brussels; 2013.

4. World Health Organization (WHO). Counterfeit Drugs: Guidelines for the Development of Measures to Combat Counterfeit Drugs. Geneva; 1999.

5. World Health Organization (WHO). Conclusions and recommendations of the who international conference on combating countefeit medicines, Declaration of Rome. Rome; 2006 Feb.

6. Medicines and Healthcare Products Regulatory Agency (MHRA). Falsified Medical Products Strategy 2012-2015. London; 2012.

7. Wijnberg B. Counterfeiting of medical products and similar crimes ('medicrime'). Strasbourg: Council Of Europe; 2013. 
8. Council of Europe. DIRECTIVE 2011/62/EU OF THE EUROPEAN PARLIAMENT AND OF THE COUNCIL of 8 June 2011 amending Directive 2001/83/EC on the Community code relating to medicinal products for human use, as regards the prevention of the entry into the legal supply chain of falsi. Brussels; 2011.

9. European Commision. Falsified medicines | Public Health [Internet].

10. European Commision. COMMISSION DELEGATED REGULATION (EU) 2016/ 161 - of 2 October 2015 - supplementing Directive 2001/ 83/ EC of the European Parliament and of the Council by laying down detailed rules for the safety features appearing on the packaging of medicinal products for human use. Brussels; 2016.

11. Nath Saha C, Bhattacharya S. Intellectual property rights: An overview and implications in pharmaceutical industry. Vol. 2, Journal of Advanced Pharmaceutical Technology and Research. Wolters Kluwer Medknow Publications; 2011. p. 88-93.

12. Cockburn I, Long G. The importance of patents to innovation: updated cross-industry comparisons with biopharmaceuticals. Expert Opin Ther Pat. 2015;25:739-42.

13. Wouters OJ, Kanavos PG, Mckee MARTIN. Comparing Generic Drug Markets in Europe and the United States: Prices, Volumes, and Spending. Milbank Q. 2017;95:554-601.

14. Kortum P, Edwards C, Richards-Kortum R. The impact of inaccurate Internet health information in a secondary school learning environment. J Med Internet Res. 2008;10.

15. Bauer EJ. Pharmaceutical packaging handbook. Boca Raton, FL: CRC Press; 2016. 1-585 p.

16. World Health Organization (WHO). Annex 9 Guidelines on packaging for pharmaceutical products. Geneva; 2002.

17. Agrawal Y, Shah R, Prajapati P. Anticounterfeit packaging technologies. J Adv Pharm Technol Res. 2010;1:368.

18. Davison M. Pharmaceutical Anti-Counterfeiting: Combating the Real Danger from Fake Drugs. Hoboken, NJ: John Wiley and Sons; 2011.

19. Zadbuke N, Shahi S, Gulecha B, Padalkar A, Thube M. Recent trends and future of pharmaceutical packaging technology. Vol. 5, Journal of Pharmacy and Bioallied Sciences. Wolters Kluwer -Medknow Publications; 2013. p. 98-110.

20. Imlau M, Fally M, Coufal $\uparrow$ H, Burr G, Sincerbox G. Holography and Optical Storage. Springer Handbook of Lasers and Optics. Springer New York; 2007. p. 1205-49.

21. Thermochromic Ink Ensures Safety of Pharmaceutical Products [Internet].

22. Jallouli Y, Paillard A, Chang J, Sevin E, Betbeder D. Influence of surface charge and inner composition of porous nanoparticles to cross blood-brain barrier in vitro. Int $\mathrm{J}$ Pharm. 2007;344:103-9.

23. Therapeutic Goods Administration. Code of Practice for the Tamper-Evident Packaging (TEP) of Therapeutic Goods Published on behalf of the Industry Government Crisis Management Committee (IGCMC) About the Therapeutic Goods Administration (TGA). Woden; 2003.

24. Kovacs S, Hawes SE, Maley SN, Mosites E, Wong L, Stergachis A. Technologies for Detecting Falsified and Substandard Drugs in Low and Middle-Income Countries. Sullivan DJ, editor. PLoS One. 2014;9:e90601. 


\title{
Uloga prava intelektualne svojine i sigurnosnih karakteristika pakovanja u prevenciji falsifikovanih lekova
}

\author{
Katerina Ančevska-Netkovska ${ }^{1 *}$, Katerina Brezovska ${ }^{2}$, \\ Nikola Geškovski ${ }^{3}$, Jasmina Tonić-Ribarska², \\ Biljana Petrovska-Jakimovska ${ }^{3,4}$, Blagoj Ačevski ${ }^{2}$, \\ Katerina Goračinova ${ }^{3 *}$
}

\author{
${ }^{1}$ Institut farmaceutske hemije, Farmaceutski fakultet, Univerzitet "Sv. Kiril i Metodij" \\ Majka Teresa 17, 1000 Skopje, Republika Severna Makedonija \\ ${ }^{2}$ Institut primenjene hemije i farmaceutske analize, Farmaceutski fakultet, Univerzitet \\ “Sv. Kiril i Metodij” Majka Teresa 17, 1000 Skopje, Republika Severna Makedonija \\ ${ }^{3}$ Institut farmaceutske tehnologije, Farmaceutski fakultet, Univerzitet "Sv. Kiril i \\ Metodij” Majka Teresa 17, 1000 Skopje, Republika Severna Makedonija \\ ${ }^{4}$ Alkaloid AD, Bul. A. Makedonski 12, 1000 Skopje, Republika Severna Makedonija \\ * Autori za korespondenciju: Katerina Ančevska Netkovska, e-mail: kaan@ff.ukim.edu.mk \\ Katerina Goračinova, e-mail: kago@ff.ukim.edu.mk
}

\section{Kratak sadržaj}

Brzi rast falsifikovanih lekova u poslednje dve decenije stvorio je jedan od najvećih problema sa kojima se susreće farmaceutska industrija na globalnom nivou, što dovodi do gubitka prihoda, povlačenje proizvoda, gubitak vrednosti brenda itd. Međutim, ovo nije samo problem prava intelektualne svojine farmaceutske industrije, već je isto tako i problem regulatornih organa, čija najznačajnija obaveza je rizik javnog zdravlja. Proizvođači farmaceutskih proizvoda, zajedno sa distributerima, imaju bitnu ulogu u borbi protiv falsifikovanih lekova primenom različitih antifalsifikovanih tehnologija za obezbeđenje lanca snabdevanja lekovima. Zaštita pakovanja lekova ima i specifičnu ulogu u procesu ravoja lekova, kao i u borbi protiv falsifikovanih lekova. Autentičnost leka i forenzičkih elemenata za zaštitu pakovanja mogu se potvrditi upotrebom različitih tehnologija. Praćenje i pronalaženje farmaceutskih proizvoda u lancu snabdevanja, vođenje elektronske evidencije svih faza distribucije i provera autentučnosti leka je ključni element i efikasno rešenje za pravovremeno otkrivanje falsifikovanih lekova i zaštite prava intelektualne svojine.

Ključne reči: prava intelektualne svojine, falsifikovanje, lekovi, pakovanje lekova 